\title{
Methane fluxes from typical marine polyculture ponds of swimming crab with kuruma shrimp and short-necked clam in eastern China
}

\author{
Dongxu Zhang ${ }^{1}$, Xiangli Tian ${ }^{1, *}$, Shuanglin Dong ${ }^{1}$, Yan Chen ${ }^{2}$, Jie Feng ${ }^{1}$, \\ Rui-Peng $\mathrm{He}^{1}$, Kai Zhang ${ }^{3}$ \\ ${ }^{1}$ Key Laboratory of Mariculture, Ministry of Education, Ocean University of China, Qingdao 266003, PR China \\ ${ }^{2}$ Beijing Aquatic Product Technology Promotion Department, Beijing 100029, PR China \\ ${ }^{3}$ Pearl River Fisheries Research Institute, Chinese Academy of Fishery Sciences, Guangzhou 510380, PR China
}

\begin{abstract}
Methane $\left(\mathrm{CH}_{4}\right)$ fluxes at the water-air interface in 2 typical seawater polyculture systems were determined during the farming season. The mean $\mathrm{CH}_{4}$ fluxes were $66.0 \pm 44.1 \mu \mathrm{g} \mathrm{m}^{-2}$ $\mathrm{h}^{-1}$ in the bispecies polyculture system of swimming crab Portunus trituberculatus with kuruma shrimp Marsupenaeus japonicus (PM) and $68.7 \pm 39.5 \mu \mathrm{g} \mathrm{m}^{-2} \mathrm{~h}^{-1}$ in the trispecies polyculture system of swimming crab with shrimp and short-necked clam Ruditapes philippinarum (PMR), and no significant differences were observed between them. $\mathrm{CH}_{4}$ emissions showed temporal variability during the farming season, peaking in mid-August. The linear mixed-effect model demonstrated that air temperature was the main regulator of $\mathrm{CH}_{4}$ fluxes rather than the internal physical and chemical properties of the systems. Air, water and sediment temperatures explained 58.9, 61.4 and $55.3 \%$ of the $\mathrm{CH}_{4}$ flux variations in the $\mathrm{PM}$ and $64.6,57.1$ and $60.8 \%$ of the variations in the PMR, respectively. Reducing organic matter accumulation in the sediment by means of improving feeding efficiency and the application of integrated aquaculture are likely to be effective in reducing $\mathrm{CH}_{4}$ emissions from aquaculture systems.
\end{abstract}

KEY WORDS: Methane fluxes $\cdot$ Temperature $\cdot$ Sediment characteristics $\cdot$ Seawater polyculture systems

\section{INTRODUCTION}

Methane $\left(\mathrm{CH}_{4}\right)$ is an important greenhouse gas (GHG) contributing to global warming. The atmospheric concentration of $\mathrm{CH}_{4}$ in 2016 was 1.853 ppm (WMO 2017), which exceeded its preindustrial level by $150 \%$ and was held responsible for $17 \%$ of the radiative forcing (IPCC 2013). Although its atmospheric concentration is relatively low compared to the major GHG carbon dioxide $\left(\mathrm{CO}_{2}\right)$, the global warming potential of $\mathrm{CH}_{4}$ is 84 times that of $\mathrm{CO}_{2}$ over a 20 yr time horizon (IPCC 2014).

$\mathrm{CH}_{4}$ fluxes at the water-air interface in aquatic ecosystems depend on $\mathrm{CH}_{4}$ formation, which occurs

\footnotetext{
${ }^{*}$ Corresponding author: xianglitian@ouc.edu.cn
}

exclusively in anaerobic environments (Utsumi et al. 1998), and $\mathrm{CH}_{4}$ oxidation during transmission from the sediment to the water-air interface (Duc et al. 2010). Any chemical, physical and biological factors that could affect $\mathrm{CH}_{4}$ formation and oxidation might potentially enhance or decrease $\mathrm{CH}_{4}$ fluxes across the water-air interface. Temperature is a strong regulator of $\mathrm{CH}_{4}$ fluxes (Svensson 1984, Williams \& Crawford 1984). Since methanogenesis is temperature dependent (Westermann et al. 1989), $\mathrm{CH}_{4}$ fluxes usually show temporal variability when measured over a long time period (Xing et al. 2005, Tong et al. 2009, Xiao et al. 2013a). Macrofaunal activities profoundly impact biogeochemical processes and micro-

() The authors 2019. Open Access under Creative Commons by Attribution Licence. Use, distribution and reproduction are unrestricted. Authors and original publication must be credited. 
bial diversity (Aller 1980, Laverock et al. 2010). However, an understanding of the impact of macrofauna on $\mathrm{CH}_{4}$ release is still limited. According to the results of an incubation experiment (Bonaglia et al. 2017), polychaetes indirectly enhance $\mathrm{CH}_{4}$ efflux by a factor of 8 through bioturbation, while bivalves have a direct positive effect on $\mathrm{CH}_{4}$ release through the colonization of active methanogens in the bivalve body, i.e. the anoxic intestine. To date, no field investigation of the effect of bivalves on $\mathrm{CH}_{4}$ emission in aquaculture systems has been reported.

Generally, lakes, reservoirs, tidal marshes, paddy fields, etc., because of the prevalence of waterlogged and anoxic conditions, are critical $\mathrm{CH}_{4}$ sources, which has been documented by numerous studies (Naser et al. 2007, Tong et al. 2010, Schubert et al. 2012, Xiao et al. 2013b). Moreover, these systems are strong $\mathrm{CH}_{4}$ emitters because sulfate reduction is generally absent or very low in nonsaline systems (Reeburgh \& Heggie 1977). However, $\mathrm{CH}_{4}$ fluxes across the water-air interface from mariculture ponds have been rarely studied until now (Chen et al. 2016, Yang et al. 2018). Mariculture ponds play important roles in coastal ecosystems. According to statistical data maintained by the Agriculture Ministry of China, the combined area of mariculture ponds in 2015 was approximately $4.6 \times 10^{3} \mathrm{~km}^{2}$, accounting for nearly $20 \%$ of the total mariculture area in China, and production was approximately $2.35 \times 10^{6}$ tons (Fisheries Department of Agriculture Ministry of China 2016), accounting for approximately $8.5 \%$ of the world's mariculture production (FAO 2017).

In mariculture ponds, feeds are normally supplied daily. However, only a small portion of the feed is converted into production, and this could be as low as 4.0 to $27.4 \%$ (Chen et al. 2016). Most of the input feed is retained in the systems or is discharged to adjacent water bodies (Su et al. 2009). This residual feed as well as the feces generated during aquaculture production could be major sources of substrates for $\mathrm{CH}_{4}$ formation. To date, some efforts have been made to characterize $\mathrm{CH}_{4}$ fluxes from mariculture ponds, and results indicated that mariculture ponds might be important $\mathrm{CH}_{4}$ emitters (Chen et al. 2016, Yang et al. 2018). However, the number of field studies on $\mathrm{CH}_{4}$ fluxes from mariculture ponds remains limited in comparison to those from other aquatic systems (e.g. lakes and reservoirs). As a result, it is difficult to assess the role that mariculture ponds play in global $\mathrm{CH}_{4}$ emissions. More importantly, the maintenance of mariculture ponds depends on the management of stocks, feeding, water exchange, etc. Different mariculture ponds often have different aquaculture management requirements, which might lead to large variations in $\mathrm{CH}_{4}$ emissions. Therefore, to better understand the potential contribution of mariculture ponds to the global $\mathrm{CH}_{4}$ budget, it is of great significance and necessity to conduct extensive studies on $\mathrm{CH}_{4}$ emissions from various mariculture ponds.

The swimming crab Portunus trituberculatus has been widely cultured in coastal China, with production reaching 117772 tons in 2015 (Fisheries Department of Agriculture Ministry of China 2016). Multispecies polyculture in marine ponds is very popular for this species, and polycultures of swimming crabs with shrimp and clams are 2 representative systems (Dong et al. 2013). In this study, we chose 2 typical seawater polyculture systems, i.e. polyculture of swimming crabs with kuruma shrimp Marsupenaeus japonicus (PM) and polyculture of swimming crabs with kuruma shrimp and short-necked clams Ruditapes philippinarum (PMR), and monitored $\mathrm{CH}_{4}$ fluxes at the water-air interface, determined during the farming season. The aims of this study were (1) to quantify $\mathrm{CH}_{4}$ fluxes at the water-air interface in the 2 typical polyculture systems and their differences and (2) to determine the main environmental factors influencing $\mathrm{CH}_{4}$ fluxes in mariculture systems.

\section{MATERIALS AND METHODS}

\subsection{Experimental ponds}

The study was carried out in the Modern Agriculture Industrial Park in Ganyu County, Jiangsu Province, China $\left(34.97^{\circ} \mathrm{N}, 119.20^{\circ} \mathrm{E}\right)$, in 2014 from July to November, which represents a typical temperate monsoonal climate. Two typical polyculture systems in marine ponds were selected: the PM was stocked with swimming crab Portunus trituberculatus and kuruma shrimp Marsupenaeus japonicus, and the PMR was stocked with swimming crab, kuruma shrimp and short-necked clam Ruditapes philippinarum. Three ponds were employed for each system, and all the ponds were oriented north-south. The pond dimensions were as follows: $170 \mathrm{~m}$ length, $60 \mathrm{~m}$ width and $2.3 \mathrm{~m}$ depth. Information on stocking biomass and yield is shown in Table 1. During the farming season, the crab and shrimp were fed mainly with Aloidis laevis and supplemented with frozen trash fish. The total feed input in the PM was the same as that in the PMR. The seawater in the ponds was routinely exchanged through water inlets and outlets during spring tides. 
Table 1. Stocking density and yield in 2 mariculture systems (mean $\pm \mathrm{SD}$ ). PM: polyculture system of swimming crab with kuruma shrimp; PMR: polyculture system of swimming crab with kuruma shrimp and shortnecked clam. (-) data not available

\begin{tabular}{|lcc|}
\hline Farming system & $\begin{array}{c}\text { Stocking density } \\
\left(10^{4} \text { ind. ha }{ }^{-1}\right)\end{array}$ & $\begin{array}{c}\text { Yield } \\
\left(\mathrm{kg} \mathrm{ha}^{-1}\right)\end{array}$ \\
\hline PM & & \\
Swimming crab & 7.2 & $758.3 \pm 15.2$ \\
Kuruma shrimp & 48 & $303.3 \pm 15.3$ \\
Short-necked clam & - & - \\
PMR & & \\
Swimming crab & 7.2 & $850.0 \pm 86.6$ \\
Kuruma shrimp & 48 & $283.3 \pm 28.9$ \\
Short-necked clam & 50 & $1866.7 \pm 189.3$ \\
\hline
\end{tabular}

\section{2. $\mathrm{CH}_{4}$ gas collection and determination}

Our study was carried out during the farming season from July to November with a sampling interval of approximately $15 \mathrm{~d}$. Three different sites in each pond were selected for the measurement of $\mathrm{CH}_{4}$ flux at the water-air interface using a static chamber technique (Xing et al. 2005, 2006). The sampling chambers, made of transparent acrylic resin, were open bottomed and cylindrical (inner diameter $30 \mathrm{~cm}$, height $50 \mathrm{~cm}$ ) and covered with aluminum foil to avoid high temperatures inside the chamber resulting from direct sunlight. A small vertical vent stopped by a silicon septum on the top was used for sampling, and a $4.5 \mathrm{~V}$ fan driven by a dry battery was used inside the chamber to better mix the air without disturbing the water-air interface. The chambers were placed on a flotation device installed at the measurement sites during sampling, keeping the lower parts of the chambers approximately $5 \mathrm{~cm}$ below the water surface. All the gas samples were taken between 09:00 and 12:00 $\mathrm{h}$, and 4 gas samples of $100 \mathrm{ml}$ were transferred from the chambers into vacuum sampling bags via polypropylene syringes at $0,10,20$ and 30 min after deployment. All the gas samples were placed in a cool box first and then taken to the laboratory.

The gas samples were analyzed as soon as possible with a GC-2010 Plus gas chromatograph (Shimadzu), which was connected to an MGS-4 gas sampler. After being driven into the MGS-4 gas sampler, $\mathrm{CH}_{4}$ was separated on the column $(2 \mathrm{~m} \times 2 \mathrm{~mm}$ stainless steel, $40^{\circ} \mathrm{C}$, packed with TDX [60-80 mesh]) and then determined with a flame ionization detector at $100^{\circ} \mathrm{C}$. The flow rate of the carrier gas $\left(\mathrm{N}_{2}\right)$ was set at $22 \mathrm{ml} \mathrm{min}{ }^{-1}$, and the flow rates of the flame gases
$\left(\mathrm{H}_{2}\right.$ and compressed air) were 20 and $30 \mathrm{ml} \mathrm{min}^{-1}$, respectively. The detection limit for $\mathrm{CH}_{4}$ was $0.3 \mathrm{ppm}$. To evaluate the precision of the measurements as well as determine the sample concentrations, standard gases (10.4 ppm for $\mathrm{CH}_{4}$ ) were measured every 4 gas samples. $\mathrm{CH}_{4}$ fluxes were calculated from the linear regression of the change in $\mathrm{CH}_{4}$ concentrations over time. The equation is as follows:

$$
F=\frac{M}{V_{0}} \cdot \frac{P}{P_{0}} \cdot \frac{T_{0}}{T} \cdot H \cdot \frac{\mathrm{d} C}{\mathrm{~d} t}
$$

where $F$ is the flux $\left(\mu \mathrm{g} \mathrm{m}^{-2} \mathrm{~h}^{-1}\right), M$ is the molar mass $\left(\mu \mathrm{g} \mathrm{mol}{ }^{-1}\right)$ of $\mathrm{CH}_{4}, P$ is the atmospheric pressure $(\mathrm{kPa}), T$ is the air absolute temperature $(\mathrm{K})$ during sampling and $H$ is the height $(\mathrm{m})$ of the chamber. $V_{0}$, $P_{0}$ and $T_{0}$ are the gas molar volume $\left(\mathrm{m}^{3} \mathrm{~mol}^{-1}\right)$, atmospheric pressure $(\mathrm{kPa})$ and air absolute temperature $(\mathrm{K})$ under standard conditions, respectively, and $\mathrm{d} c / \mathrm{d} t$ is the slope of the gas concentration $(c, \mathrm{ppm})$ curve variation over time $(t, \mathrm{~h})$.

\subsection{Environmental factor determination}

Meteorological factors were collected in situ when collecting the gas. Wind velocity $(3 \mathrm{~m}$ above the water surface) and air temperature were measured by a portable anemometer (AVM-03, TES Electrical Electronic). Meanwhile, 9 water samples (surface, middle and bottom water layers at 3 different sites) were taken from each pond with a horizontal sampler. Water temperature and dissolved oxygen (DO) were measured with a YSI DO meter (Model 5000, $230 \mathrm{~V})$, water $\mathrm{pH}$ and redox potential were determined with a $\mathrm{pH} / \mathrm{mV}$ meter (IQ150, Spectrum), and water salinity was determined by a portable refractometer in situ when collecting the water samples. Sediment $\mathrm{pH}$ and redox potential (at $3 \mathrm{~cm}$ depth) were also measured with a $\mathrm{pH} / \mathrm{mV}$ meter (IQ150, Spectrum) after sediment cores were taken with a sediment corer.

Water samples were stored in 11 polyethylene bottles separately and then immediately taken to the laboratory. The total nitrogen (TN) and total phosphorus (TP) concentrations of the water samples were analyzed by the method of simultaneous digestion introduced by Valderrama (1981), and the detection limits for TN and TP were 0.05 and $0.003 \mathrm{mg}$ $\mathrm{l}^{-1}$, respectively. After water samples were filtered through GF/F glass microfiber filters, the filters were extracted with acetone $(90 \%)$ in darkness for $24 \mathrm{~h}$, and then chl a was analyzed according to the method of the National Standardization Management Coun- 
cil (2007). $\mathrm{NO}_{3}{ }^{-}-\mathrm{N}, \mathrm{NO}_{2}{ }^{-}-\mathrm{N}, \mathrm{NH}_{4}{ }^{+}-\mathrm{N}$ and $\mathrm{PO}_{4}{ }^{3-}-\mathrm{P}$ concentrations were determined using the filtrate. $\mathrm{NO}_{3}{ }^{-}-\mathrm{N}$ was analyzed with the cadmium-copper column reduction method according to Hansen \& Koroleff (1999), and the detection limit was $0.6 \times 10^{-3} \mathrm{mg}$ $\mathrm{l}^{-1}$. $\mathrm{NO}_{2}{ }^{-}-\mathrm{N}$ concentration was determined by the method of Bendschneider \& Robinson (1952), with a detection limit of $0.3 \times 10^{-3} \mathrm{mg} \mathrm{l}^{-1}$. $\mathrm{NH}_{4}{ }^{+}-\mathrm{N}$ was measured with the indophenol blue method according to Sagi (1966), and the detection limit was $0.7 \times 10^{-3} \mathrm{mg}$ $\mathrm{l}^{-1} \cdot \mathrm{PO}_{4}{ }^{3}-\mathrm{P}$ concentration was analyzed by the method introduced by Murphy \& Riley (1962), with a detection limit of $0.6 \times 10^{-3} \mathrm{mg} \mathrm{l}^{-1}$. The sediment cores $(0-10 \mathrm{~cm})$ were sampled using a cylindrical metal corer (diameter $8 \mathrm{~cm}$ ) and then dried at $60^{\circ} \mathrm{C}$ to a constant weight, ground and sieved with a sample sifter. The organic matter content of the sediment cores was measured by the combustion method according to Piron et al. (1990).

\subsection{Data analysis}

The data were analyzed with the statistical software SPSS 17.0. Differences in the environmental variables between the different culture systems were analyzed using a Student's $t$-test. Correlations between $\mathrm{CH}_{4}$ flux and the measured variables were tested using curve estimation or Pearson correlation analysis. To examine the associations between $\mathrm{CH}_{4}$ flux and the environmental factors measured, a linear mixed-effect model was applied to the PM and PMR datasets. In the model, the intercept, sampling time, aquaculture system, interaction between sampling time and system, wind velocity, air temperature, water $\mathrm{pH}, \mathrm{DO}$, redox potential in water, $\mathrm{chl} a_{\text {, }}$ $\mathrm{NO}_{3}{ }^{-}-\mathrm{N}, \mathrm{NO}_{2}{ }^{-}-\mathrm{N}, \mathrm{NH}_{4}{ }^{+}-\mathrm{N}, \mathrm{PO}_{4}{ }^{3-}-\mathrm{P}, \mathrm{TN}, \mathrm{TP}$, sediment redox potential, $\mathrm{pH}$ and organic matter content were fitted as fixed effects, and the intercept and the system were specified as random effects. The firstorder autoregressive was selected as the covariance structure.

\section{RESULTS}

\subsection{Variations in environmental factors}

Wind velocity during the farming season averaged $2.0 \mathrm{~m} \mathrm{~s}^{-1}\left(0.8-3.9 \mathrm{~m} \mathrm{~s}^{-1}\right)$. Air and water temperatures varied similarly during the farming season, with the maximum (28.1 and $27.2^{\circ} \mathrm{C}$, respectively) occurring in mid-August and the minimum $\left(12.9\right.$ and $12.0^{\circ} \mathrm{C}$, respectively) occurring at the end of the farming season (Fig. 1b). Water salinity in the PM and the PMR varied similarly during the farming season, with the minimum occurring on 3 August and 18 September (Fig. 1a), respectively, which was mostly related to a heavy rainstorm before the sampling days.

As shown in Fig. 1c, water $\mathrm{pH}$ in the PM averaged 8.32 (7.96-8.79) during the farming season, which was significantly higher than that in the PMR $(\mathrm{p}<$ 0.01) (mean 7.90, 7.78-7.97). During the farming season, no significant differences in DO concentrations were found between the PM and the PMR ( $p>0.05)$ (mean 8.42 and $7.36 \mathrm{mg} \mathrm{l}^{-1}$, respectively) (Fig. 1d), and there was also no significant difference in the water redox potential between the PM and the PMR (mean 86.8 and $102.0 \mathrm{mV}$, respectively) ( $\mathrm{p}>0.05$ ) (Fig. 1e). Chl a concentrations in the water are shown in Fig. 1f. Chl a concentrations in the PM (mean $44.5 \mathrm{mg} \mathrm{m}^{-3}, 21.2-103.0 \mathrm{mg} \mathrm{m}^{-3}$ ) were significantly higher than those in the PMR (mean $15.8 \mathrm{mg} \mathrm{m}^{-3}$, $\left.7.8-30.3 \mathrm{mg} \mathrm{m}^{-3}\right)(\mathrm{p}<0.05)$.

Concentrations of water nutrients in the PM and the PMR during the farming season are shown in Table 2. No significant differences in the concentrations of $\mathrm{NO}_{2}{ }^{-}-\mathrm{N}, \mathrm{NH}_{4}{ }^{+}-\mathrm{N}$ and $\mathrm{PO}_{4}{ }^{3-}-\mathrm{P}$ were found between the PM and the PMR. $\mathrm{NO}_{3}{ }^{-}-\mathrm{N}$ concentrations in the PM were significantly lower than those in the PMR $(p<0.05)$, while TN and TP concentrations in the PM were significantly higher than those in the PMR $(\mathrm{p}<0.05)$.

As shown in Table 3, $\mathrm{pH}$ and redox potential in the sediment were lower than those in the water, while the average sediment temperature was higher than the water temperature (Fig. 1). Among the measured physical and chemical factors of the sediment, a significant difference was only found in the redox potential $(\mathrm{p}<0.05)$, while the $\mathrm{pH}$, temperature and organic matter content of the sediment showed no significant differences between the PM and the PMR $(\mathrm{p}>0.05)$.

\section{2. $\mathrm{CH}_{4}$ fluxes in the $P M$ and the PMR during the farming season}

Variations in $\mathrm{CH}_{4}$ fluxes in the PM and the PMR during the farming season are shown in Fig. 2. The PM and PMR culture systems both acted as stable $\mathrm{CH}_{4}$ sources to the atmosphere, with average fluxes of 66.0 and $68.7 \mu \mathrm{g} \mathrm{m}^{-2} \mathrm{~h}^{-1}$, respectively, and no difference was observed between them $(p>0.05)$. During the farming season, $\mathrm{CH}_{4}$ fluxes in the $\mathrm{PM}$ and 

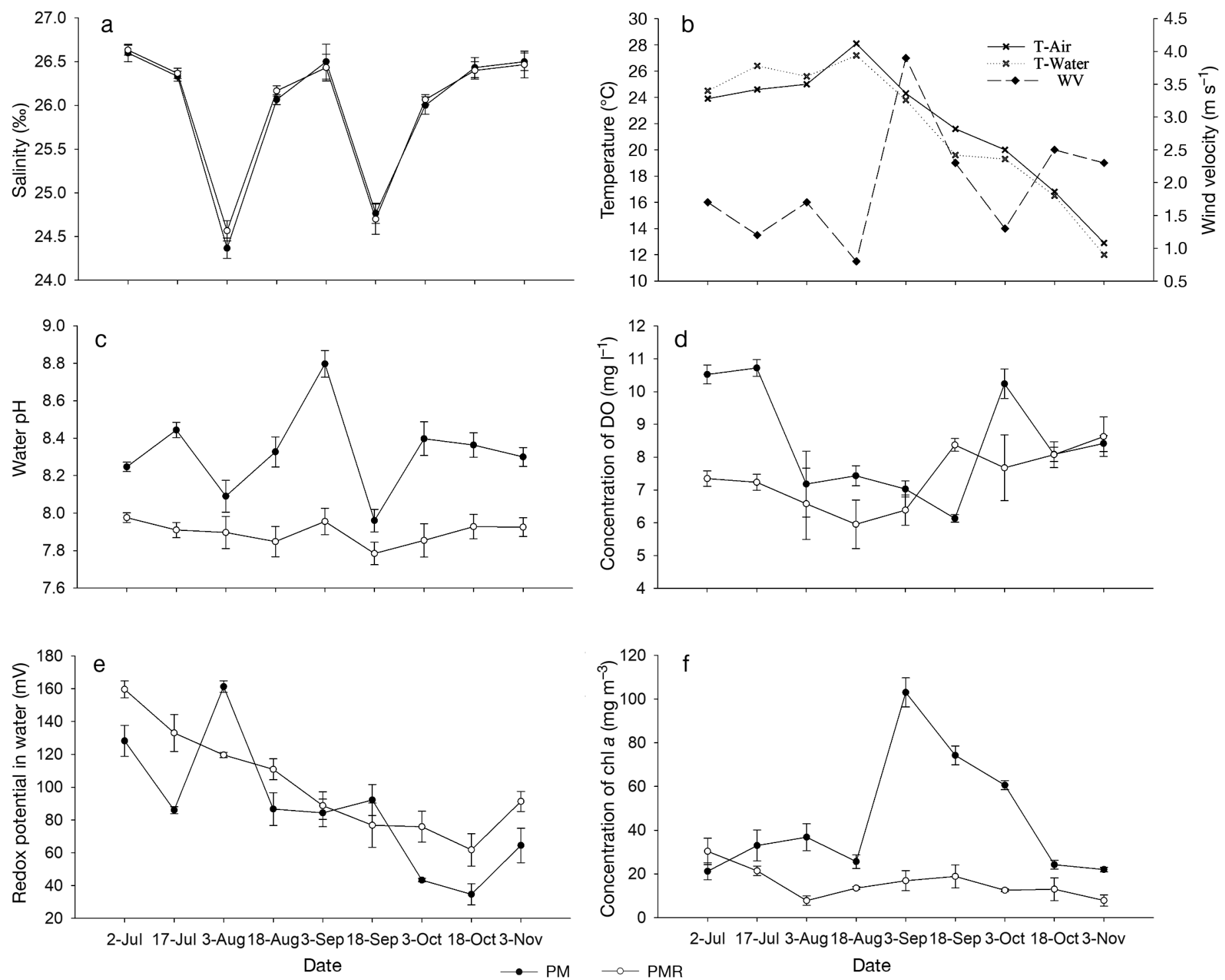

Fig. 1. Variations in salinity, wind velocity (WV), temperature (T), water $\mathrm{pH}$, dissolved oxygen (DO), water redox potential and chl $a$ in the PM and the PMR (defined in Table 1) during the farming seasons

the PMR generally increased from the beginning of the farming season, peaked in mid-August $(143.8 \mu \mathrm{g}$ $\mathrm{m}^{-2} \mathrm{~h}^{-1}$ in the PM and $139.0 \mu \mathrm{g} \mathrm{m}^{-2} \mathrm{~h}^{-1}$ in the PMR), and were followed by a reduction before reaching the lowest points at the end of the farming season $\left(21.9 \mu \mathrm{g} \mathrm{m}^{-2} \mathrm{~h}^{-1}\right.$ in the PM and $11.2 \mu \mathrm{g} \mathrm{m}^{-2} \mathrm{~h}^{-1}$ in the PMR).

\subsection{Correlations between $\mathrm{CH}_{4}$ fluxes and environmental factors measured}

As shown in Fig. 3, the exponential model could be used to describe the relationship between $\mathrm{CH}_{4}$ fluxes from the PM and the PMR and the temperatures of air, water and sediment, and all the fitting equations

Table 2. Concentrations of water nutrients in different polyculture systems (PM and PMR, defined in Table 1) during the farming season (mean \pm SD). Data in the same column with different superscripts indicate significant differences $(p<0.05)$

\begin{tabular}{|lcccccc|}
\hline System & $\mathrm{NO}_{3}{ }^{-}-\mathrm{N}\left(\mathrm{mg} \mathrm{l}^{-1}\right)$ & $\mathrm{NO}_{2}{ }^{-}-\mathrm{N}\left(\mathrm{mg} \mathrm{l}^{-1}\right)$ & $\mathrm{NH}_{4}{ }^{+}-\mathrm{N}\left(\mathrm{mg} \mathrm{l}^{-1}\right)$ & $\mathrm{PO}_{4}{ }^{3-}-\mathrm{P}\left(\mathrm{mg} \mathrm{l}^{-1}\right)$ & $\mathrm{TN}\left(\mathrm{mg} \mathrm{l}^{-1}\right)$ & $\mathrm{TP}\left(\mathrm{mg} \mathrm{l}^{-1}\right)$ \\
\hline $\mathrm{PM}$ & $0.21 \pm 0.16^{\mathrm{a}}$ & $0.057 \pm 0.039$ & $0.063 \pm 0.054$ & $0.014 \pm 0.005$ & $3.66 \pm 0.52^{\mathrm{b}}$ & $0.22 \pm 0.065^{\mathrm{b}}$ \\
$\mathrm{PMR}$ & $0.47 \pm 0.25^{\mathrm{b}}$ & $0.089 \pm 0.030$ & $0.052 \pm 0.027$ & $0.022 \pm 0.015$ & $3.13 \pm 0.40^{\mathrm{a}}$ & $0.14 \pm 0.032^{\mathrm{a}}$ \\
\hline
\end{tabular}


Table 3. Physical and chemical factors of the sediment in different polyculture systems (PM and PMR, defined in Table 1) during the farming season (mean \pm SD). Data in the same column with different superscripts indicate significant differences $(\mathrm{p}<0.05)$

\begin{tabular}{|lcccc|}
\hline Systems & $\mathrm{pH}$ & $\begin{array}{c}\text { Redox potential } \\
(\mathrm{mV})\end{array}$ & $\begin{array}{c}\text { Temperature } \\
\left({ }^{\circ} \mathrm{C}\right)\end{array}$ & $\begin{array}{c}\text { Organic } \\
\text { matter }(\%)\end{array}$ \\
\hline PM & $7.72 \pm 0.27$ & $-152.2 \pm 25.9^{\mathrm{a}}$ & $23.0 \pm 4.8$ & $3.96 \pm 0.51$ \\
PMR & $7.58 \pm 0.15$ & $-121.5 \pm 26.0^{\mathrm{b}}$ & $22.9 \pm 4.9$ & $4.16 \pm 0.51$ \\
\hline
\end{tabular}

\section{DISCUSSION}

\subsection{Factors influencing $\mathrm{CH}_{4}$ emissions}

Temperature is a strong regulator of $\mathrm{CH}_{4}$ fluxes (Svensson 1984, Williams \& Crawford 1984). The temporal variability of $\mathrm{CH}_{4}$ emissions is normally found to be positively related to temperature when measuring over longer time periods, and the connections between temperature were significant $(p=0.000)$. Air, water and sediment temperatures explained $58.9,61.4$ and $55.3 \%$ of the $\mathrm{CH}_{4}$ flux variations in the PM and 64.6, 57.1 and $60.8 \%$ of the $\mathrm{CH}_{4}$ flux variations in the PMR, respectively.

According to the Pearson correlation analysis, $\mathrm{CH}_{4}$ flux in the PM was correlated significantly with $\mathrm{NO}_{3}{ }^{-}-\mathrm{N}(\mathrm{r}=-0.553, \mathrm{p}<0.01)$ and $\mathrm{NO}_{2}{ }^{-}-\mathrm{N}(\mathrm{r}=-0.465$, $\mathrm{p}<0.05)$ concentrations in the water. In the PMR, a significant correlation was found only between $\mathrm{CH}_{4}$ emission and wind velocity $(\mathrm{r}=-0.515, \mathrm{p}<0.01)$.

The results of estimates of the fixed effects demonstrated that sampling time was not significant in predicting $\mathrm{CH}_{4}$ flux and neither was aquaculture system ( $p>0.05$, see Table A1 in the Appendix). The interaction between sampling time and aquaculture system was also found to be insignificant ( $p>0.05$ ). Among all the environmental variables measured, air temperature was the only factor significantly correlated with $\mathrm{CH}_{4}$ flux $(\mathrm{p}<0.01)$. According to estimates of the covariance parameters (see Table A2), the variance of the random errors for repeated measures was estimated to be 528.899, which was significant ( $\mathrm{p}=$ 0.000 ). The variance of the random errors for the random variables in the model was estimated to be $3.140(p=0.874)$.

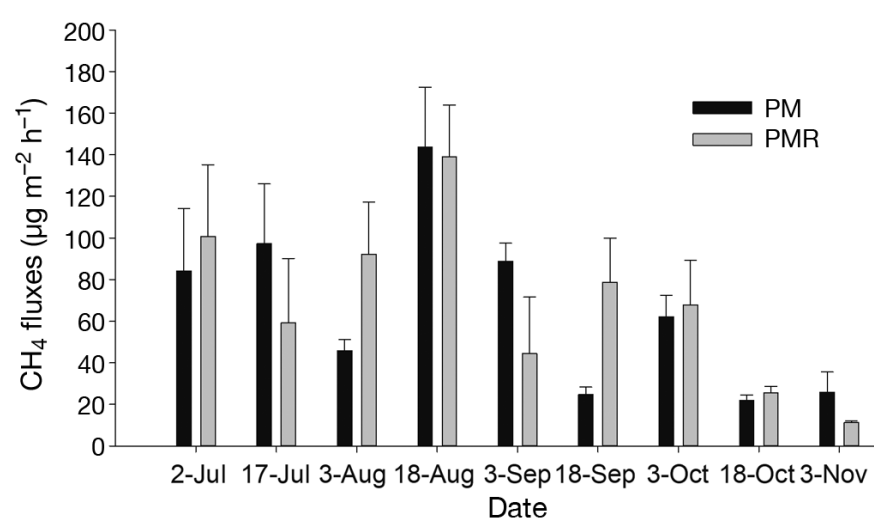

Fig. 2. Variations in methane $\left(\mathrm{CH}_{4}\right)$ fluxes in the $\mathrm{PM}$ and the PMR (defined in Table 1) during the farming season and $\mathrm{CH}_{4}$ fluxes range from linear to exponential (e.g. Xing et al. 2005, Frei et al. 2007, Tong et al. 2009, Xiao et al. 2013a). In the present study, $\mathrm{CH}_{4}$ fluxes in both the PM and the PMR showed an obvious seasonal trend, peaking in mid-August and being relatively low at the beginning and later parts of the farming season, and the $\mathrm{CH}_{4}$ fluxes tended to be consistent with the temperature. Results of the correlation analysis showed that the relationships between $\mathrm{CH}_{4}$ emissions and temperature could be best described as an exponential model, and the temperatures of air, water and sediment explained 58.9, 61.4 and $55.3 \%$ of the $\mathrm{CH}_{4}$ flux variations in the $\mathrm{PM}$ and $64.6,57.1$ and $60.8 \%$ of the $\mathrm{CH}_{4}$ flux variations in the PMR, respectively. Additionally, results of the linear mixed-effect model also demonstrated that air temperature, among all the variables measured, was the only factor positively correlated with $\mathrm{CH}_{4}$ flux ( $\mathrm{p}<$ 0.05). Furthermore, sampling time and the different aquaculture systems were found to have no significant effect on $\mathrm{CH}_{4}$ flux, which means that under the conditions of the present study, $\mathrm{CH}_{4}$ emissions were barely regulated by the stocked animals in the systems or the different developmental stages of the aquaculture systems. These results suggest that the external meteorological factors (mainly temperature) rather than the internal physical and chemical properties of the system dominate the $\mathrm{CH}_{4}$ emission pattern in this study. In contrast, our study on $\mathrm{CO}_{2}$ flux from the present aquaculture systems indicated that $\mathrm{CO}_{2}$ flux at the water-air surface was strongly driven by their internal biological and physicochemical characteristics, and any factor that influenced their internal biogeochemical process (e.g. management methods, biological characteristics of stocked species) could have impacts on $\mathrm{CO}_{2}$ emission patterns in aquaculture systems (D. Zhang et al. unpubl. data). The positive effect of temperature on $\mathrm{CH}_{4}$ emissions may be related to the following aspects. First, methanogenesis is temperature dependent, similar to most other metabolic activities (Westermann et al. 1989). Temperature can affect the population of methano- 

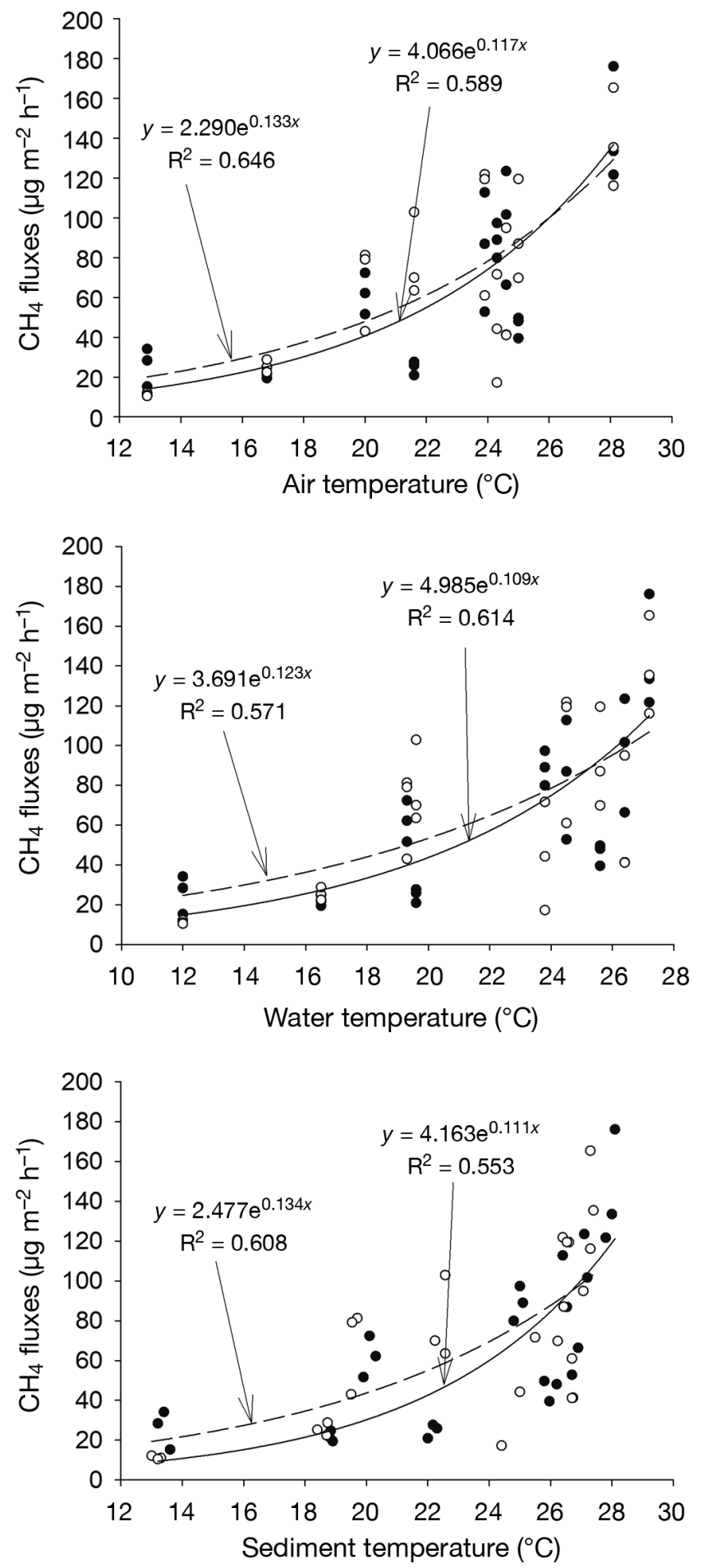

- PM

OPMR

Fig. 3. Relationships between methane $\left(\mathrm{CH}_{4}\right)$ fluxes and air, water and sediment temperature in the PM and the PMR (defined in Table 1)

gens, and higher temperatures favor the domination of species that are more powerful in utilizing substrates and producing $\mathrm{CH}_{4}$ (Sekiguchi et al. 1998, Ding
\& Cai 2003). Second, a substrate is an essential requirement for methanogenesis. Since methanogenic substrates mostly originate from the metabolic activities of other microorganisms, substrate availability is always involved in temperature responses. For instance, temperature could limit hydrogen turnover and hence the availability of a substrate to a greater extent than methanogenic activity (Conrad et al. 1987). Third, higher temperatures reduce the solubility of $\mathrm{CH}_{4}$ in the water column, promoting $\mathrm{CH}_{4}$ evasion from water during transport.

In the present study, we found that $\mathrm{NO}_{3}{ }^{-}-\mathrm{N}$ and $\mathrm{NO}_{2}{ }^{-}-\mathrm{N}$ concentrations were both negatively correlated with $\mathrm{CH}_{4}$ emissions in the PM ( $\mathrm{p}<0.01$ and $\mathrm{p}<$ 0.05 , respectively), which might be interpreted as being due to the competition for substrates by denitrifiers. $\mathrm{CH}_{4}$ is mainly generated from precursor substrates, such as acetic acid and $\mathrm{H}_{2} / \mathrm{CO}_{2}$, by methanogens. However, denitrifying bacteria could compete for common substrates with methanogens (Klüber \& Conrad 1998), resulting in a decrease in $\mathrm{CH}_{4}$ production. Meanwhile, $\mathrm{NO}_{2}{ }^{-}-\mathrm{N}$, an important denitrification intermediate, is toxic to methanogens and hence inhibits methanogenesis and suppresses $\mathrm{CH}_{4}$ production (Balderston \& Payne 1976, Roy \& Conrad 1999).

In this study, $\mathrm{CH}_{4}$ emissions from the $\mathrm{PM}$ and the PMR were 66.0 and $68.7 \mu \mathrm{g} \mathrm{m}^{-2} \mathrm{~h}^{-1}$, respectively, during the farming season, and on the whole, no significant difference was found between the 2 systems $(p>0.05)$. The correlation analysis showed that the differences in sediment variables between the PM and the PMR were observed to be insignificant $(p>0.05)$, though some water environmental variables, such as $\mathrm{pH}, \mathrm{TN}, \mathrm{TP}$ and chl $a$, were remarkably different $(p<0.05)$, which suggests that $\mathrm{CH}_{4}$ emissions from the present systems may mostly be correlated with the characteristics of sediment rather than the water environmental factors, especially given the shallow water table in the present study. Bivalve activities such as biodeposition and bioturbation could alter the physical and chemical characteristics of sediment (Vaughn \& Hakenkamp 2001, Newell 2004) and thus affect $\mathrm{CH}_{4}$ emissions (Bonaglia et al. 2017). However, the results of the present study do not seem to fit well with previous understandings. This is probably because even though biodeposition could increase the organic matter content, the bioturbation of sediments through bivalve movements could increase the oxygen content in the sediments and consequently inhibit methanogenesis. Moreover, it was reported that a higher stocking density of bivalves could promote 
$\mathrm{CH}_{4}$ production (Wang 2008), and the stocking density of the clam in this study may have been too low to lead to a significant difference between the PM and the PMR. However, it is worth noting that $\mathrm{CH}_{4}$ fluxes on 3 August and 18 September in the PMR were significantly higher than those in the PM $(\mathrm{p}<$ 0.05 ). This may be related to a heavy rainstorm before the sampling days. The sudden drop in water salinity could cause metabolic changes in the clam, such as increasing their oxygen consumption (Nie et al. 2017), which can result in oxygen depletion in the interstitial water and thereby promote $\mathrm{CH}_{4}$ production and emission.

\subsection{Comparisons of $\mathrm{CH}_{4}$ flux with other aquatic ecosystems}

$\mathrm{CH}_{4}$ fluxes across the water-air interface from mariculture ponds have rarely been studied until now. Compared with other aquatic systems, $\mathrm{CH}_{4}$ fluxes from the PM and the PMR are 2 or 3 orders of magnitude lower than those reported for natural ecosystems such as lakes and reservoirs (Xing et al. 2005, Schrier-Uijl et al. 2011). Chen et al. (2016) reported that the $\mathrm{CH}_{4}$ flux in a shrimp mariculture pond was $65.1 \mu \mathrm{g} \mathrm{m}^{-2} \mathrm{~h}^{-1}$, which is quite close to the results of the present study. We speculated that the lower organic matter content might be the main reason explaining the lower $\mathrm{CH}_{4}$ fluxes. Average organic matter contents in the PM and the PMR were 4.16 and $4.06 \%$, respectively, 1 order of magnitude less than those in lakes and reservoirs (e.g. Huttunen et al. 2006, Hahn-Schöfl et al. 2011, Schrier-Uijl et al. 2011). The low availability of organic matter could have greatly limited $\mathrm{CH}_{4}$ production. In aquaculture ponds, residual feeds are an important source of organic matter in the sediment. However, in this study, the use of live feed together with a reasonable feeding strategy may likely have mitigated the accumulation of organic matter in the sediment and hence avoided deterioration of the sediment environment. Moreover, crab and shrimp in the present study normally inhabit the bottom. Bioturbation of the sediment by stocked animals could cause sediment resuspension and increase organic matter degradation (Xiong et al. 2017). In addition, unlike lakes and reservoirs that have been inundated for decades or even centuries, aquaculture ponds are dried and dredged annually after harvesting. As a result, a large amount of organic matter in the sediments could have been oxidized after being exposed to air and sunlight.
Based on the above understanding, to reduce $\mathrm{CH}_{4}$ emissions from aquaculture systems, reducing the accumulation of organic matter in the sediment is likely an effective method. Accordingly, the amount of uneaten feed as well as the feces from stocked animals, which constitute the major portion of the organic matter in the sediment, should be decreased as much as possible. On the one hand, given that the feed utilization efficiency is normally low in many aquaculture systems, reasonable feeding strategies that correspond to specific aquaculture patterns should be established. A proper feeding method and feeding frequency could improve feed utilization (Biswas et al. 2006, Casillas-Hernández et al. 2006, Silva et al. 2007) and thus minimize the production of organic solids. On the other hand, reductions in solid waste can also be achieved through feed formulation optimization. Highly digestible diets have been introduced as a solution to reduce solid waste excretion (Amirkolaie 2011). In addition, applications of integrated aquaculture could also be practical. A proper combination of different trophic levels of animals in aquaculture systems could make the most efficient use of the nutrients and thus reduce organic matter accumulation in the sediment or even improve the sediment environment. For example, as a type of deposit-feeding animal, sea cucumber could efficiently ingest the organic solids in polyculture systems (Yokoyama 2013, Yu et al. 2014). Therefore, it is usually considered an ideal candidate species to improve the properties of the sediment environment. A recent study indicated that a polyculture system of shrimp with sea cucumber was a significantly weaker $\mathrm{CH}_{4}$ emitter than the shrimp culture system (Chen et al. 2016). In future studies, the role of deposit-feeding animals on $\mathrm{CH}_{4}$ dynamics should be given more attention.

\section{CONCLUSIONS}

$\mathrm{CH}_{4}$ emissions from the PM and the PMR were 66.0 and $68.7 \mu \mathrm{g} \mathrm{m}^{-2} \mathrm{~h}^{-1}$, respectively, during the farming season. Clam farming seems to have little impact on $\mathrm{CH}_{4}$ emissions in the present study, although in situations such as a sudden salinity drop, clams could promote $\mathrm{CH}_{4}$ emissions. Temperature factors were positively correlated with $\mathrm{CH}_{4}$ fluxes, and $\mathrm{CH}_{4}$ emissions showed temporal variability during the farming season. Mariculture ponds in this study served as weak $\mathrm{CH}_{4}$ sources to the atmosphere, and the low availability of organic matter in the sediment might be the main reason why $\mathrm{CH}_{4}$ fluxes from the aqua- 
culture ponds were much lower than those reported for lakes and reservoirs. Feeding efficiency improvement by establishing corresponding feeding strategies and optimizing feed formulation for specific aquaculture patterns as well as the application of integrated aquaculture are likely to be practicable and effective ways to reduce $\mathrm{CH}_{4}$ emissions and mitigate global warming.

Acknowledgements. This study was funded by the National Great Project of Scientific and Technical Supporting Programs (Grant No. 2011BAD13B03) and the Programs for Excellent Youth Foundation of Shandong Province (Grant No. JQ201009).

\section{LITERATURE CITED}

Aller RC (1980) Quantifying solute distributions in the bioturbated zone of marine sediments by defining an average microenvironment. Geochim Cosmochim Acta 44: 1955-1965

Amirkolaie AK (2011) Reduction in the environmental impact of waste discharged by fish farms through feed and feeding. Rev Aquacult 3:19-26

Balderston WL, Payne WJ (1976) Inhibition of methanogenesis in salt marsh sediments and whole-cell suspensions of methanogenic bacteria by nitrogen oxides. Appl Environ Microbiol 32:264-269

Bendschneider K, Robinson RJ (1952) A new spectrophotometric method for the determination of nitrite in sea water. J Mar Res 11:87-96

Biswas G, Jena JK, Singh SK, Patmajhi P, Muduli HK (2006) Effect of feeding frequency on growth, survival and feed utilization in mrigal, Cirrhinus mrigala, and rohu, Labeo rohita, during nursery rearing. Aquaculture 254:211-218

Bonaglia S, Brüchert V, Callac N, Vicenzi A, Fru EC, Nascimento FJ (2017) Methane fluxes from coastal sediments are enhanced by macrofauna. Sci Rep 7:13145

Casillas-Hernández R, Magallón-Barajas F, Portillo-Clarck G, Páez-Osuna F (2006) Nutrient mass balances in semiintensive shrimp ponds from Sonora, Mexico using two feeding strategies: trays and mechanical dispersal. Aquaculture 258:289-298

Chen Y, Dong S, Wang F, Gao Q, Tian X (2016) Carbon dioxide and methane fluxes from feeding and no-feeding mariculture ponds. Environ Pollut 212:489-497

Conrad R, Schütz H, Babbel M (1987) Temperature limitation of hydrogen turnover and methanogenesis in anoxic paddy soil. FEMS Microbiol Ecol 45:281-289

Ding W, Cai Z (2003) Effect of temperature on methane production and oxidation in soils. Ying Yong Sheng Tai Xue Bao 14:604-608 (in Chinese with English Abstract)

Dong J, Tian XL, Dong SL, Zhang K, Feng J, He RP (2013) Study on nitrogen and phosphorus budget in polyculture systems of Litopenaeus vannamei and Portunus trituberculatus. J Ocean Univ China 43:16-24 (in Chinese with English Abstract)

Duc NT, Crill P, Bastviken D (2010) Implications of temperature and sediment characteristics on methane formation and oxidation in lake sediments. Biogeochemistry 100: 185-196
FAO (Food and Agriculture Organization of the United Nations) (2017) FAO aquaculture newsletter No. 56, April 2017. FAO, Rome

Fisheries Department of Agriculture Ministry of China (2016) China fishery statistical yearbook 2016. China Agriculture Press, Beijing (in Chinese)

Frei M, Razzak MA, Hossain MM, Oehme M, Dewan S, Becker K (2007) Methane emissions and related physicochemical soil and water parameters in rice-fish systems in Bangladesh. Agr Ecosyst Environ 120:391-398

Hahn-Schöfl M, Zak D, Minke M, Gelbrecht J, Augustin J, Freibauer A (2011) Organic sediment formed during inundation of a degraded fen grassland emits large fluxes of $\mathrm{CH}_{4}$ and $\mathrm{CO}_{2}$. Biogeosciences 8:1539

Hansen HP, Koroleff F (1999) Determination of nutrients. In: Grasshoff K, Kremling K, Ehrhardt M (eds) Methods of seawater analysis, 3rd edn. Wiley-VCH, Weinheim, p $180-187$

Huttunen JT, Väisänen TS, Hellsten SK, Martikainen PJ (2006) Methane fluxes at the sediment-water interface in some boreal lakes and reservoirs. Boreal Environ Res 11: $27-34$

IPCC (Intergovernmental Panel on Climate Change) (2013) Climate change 2013: the physical science basis. In: Stocker TF, Qin D, Plattner GK, Tignor M and others (eds) Contribution of Working Group I to the Fifth Assessment Report of the Intergovernmental Panel on Climate Change. Cambridge University Press, Cambridge, p 1535

IPCC (2014) Climate change 2014: synthesis report. In: Core Writing Team, Pachauri RK, Meyer LA (eds) Contribution of Working Groups I, II and III to the Fifth Assessment Report of the Intergovernmental Panel on Climate Change. IPCC, Geneva, p 151

K Klüber HD, Conrad R (1998) Inhibitory effects of nitrate, nitrite, $\mathrm{NO}$ and $\mathrm{N}_{2} \mathrm{O}$ on methanogenesis by Methanosarcina barkeri and Methanobacterium bryantii. FEMS Microbiol Ecol 25:331-339

* Laverock B, Smith CJ, Tait K, Osborn AM, Widdicombe S, Gilbert JA (2010) Bioturbating shrimp alter the structure and diversity of bacterial communities in coastal marine sediments. ISME J 4:1531

*Murphy J, Riley JP (1962) A modified single solution method for the determination of phosphate in natural waters. Anal Chim Acta 27:31-36

Naser HM, Nagata O, Tamura S, Hatano R (2007) Methane emissions from five paddy fields with different amounts of rice straw application in central Hokkaido, Japan. Soil Sci Plant Nutr 53:95-101

National Standardization Management Council (2007) GB/T12763.6. Part 6: marine biological survey. In: Specifications for oceanographic survey. China Standards Press, Beijing, p 6-7 (in Chinese)

Newell RI (2004) Ecosystem influences of natural and cultivated populations of suspension-feeding bivalve molluscs: a review. J Shellfish Res 23:51-62

Nie H, Chen P, Huo Z, Chen Y, Hou X, Yang F, Yan X (2017) Effects of temperature and salinity on oxygen consumption and ammonia excretion in different colour strains of the Manila clam, Ruditapes philippinarum. Aquacult Res 48:2778-2786

* Piron M, Pineau A, Mabele RM (1990) Sediment, parameters and distribution of metals in fine sediments of the Loire estuary. Water Air Soil Pollut 50:267-277

* Reeburgh WS, Heggie DT (1977) Microbial methane con- 
sumption reactions and their effect on methane distributions in freshwater and marine environments. Limnol Oceanogr 22:1-9

Roy R, Conrad R (1999) Effect of methanogenic precursors (acetate, hydrogen, propionate) on the suppression of methane production by nitrate in anoxic rice field soil. FEMS Microbiol Ecol 28:49-61

Sagi T (1966) Determination of ammonia in sea water by the indophenol method and its application to the coastal and offshore waters. Oceanogr Mag 18:43-51

Schrier-Uijl AP, Veraart AJ, Leffelaar PA, Berendse F, Veenendaal EM (2011) Release of $\mathrm{CO}_{2}$ and $\mathrm{CH}_{4}$ from lakes and drainage ditches in temperate wetlands. Biogeochemistry 102:265-279

Schubert CJ, Diem T, Eugster W (2012) Methane emissions from a small wind shielded lake determined by eddy covariance, flux chambers, anchored funnels, and boundary model calculations: a comparison. Environ Sci Technol 46:4515

Sekiguchi Y, Kamagata Y, Syutsubo K, Ohashi A, Harada H, Nakamura K (1998) Phylogenetic diversity of mesophilic and thermophilic granular sludges determined by $16 \mathrm{~S}$ rRNA gene analysis. Microbiology 144:2655-2665

Silva CR, Gomes LC, Brandão FR (2007) Effect of feeding rate and frequency on tambaqui (Colossoma macropomum) growth, production and feeding costs during the first growth phase in cages. Aquaculture 264:135-139

Su Y, Ma S, Tian X, Dong S (2009) An experimental study on nitrogen, phosphorus and carbon budgets in intensive pond of shrimp Fenneropenaeus chinensis. Nanfang Shuichan Kexue 5:54-58 (in Chinese with English Abstract)

Svensson BH (1984) Different temperature optima for $\mathrm{CH}_{4}$ formation when enrichments from acid peat are supplemented with acetate or hydrogen. Appl Environ Microbiol 48:389-394

Tong C, Zeng C, Wang W, Yan Z, Yang H (2009) Main factors influencing $\mathrm{CH}_{4}$ flux from a Phragmites australis wetland in the Min River estuary. Acta Sci Circum 29: 207-216 (in Chinese with English Abstract)

Tong C, Wang WQ, Zeng CS, Marrs R (2010) Methane $\left(\mathrm{CH}_{4}\right)$ emission from a tidal marsh in the Min River estuary, southeast China. J Environ Sci Health A Tox Hazard Subst Environ Eng 45:506-516

Utsumi M, Nojiri Y, Nakamura T, Nozawa T, Otsuki A (1998) Oxidation of dissolved methane in a eutrophic, shallow lake. Limnol Oceanogr 43:471-480

Valderrama JC (1981) The simultaneous analysis of total nitrogen and total phosphorus in natural waters. Mar Chem 10:109-122

Vaughn CC, Hakenkamp CC (2001) The functional role of burrowing bivalves in freshwater ecosystems. Freshw Biol 46:1431-1446

Wang $\mathrm{J}$ (2008) Emissions of $\mathrm{CH}_{4}$ in the sediment of cultured area and its impact factors. MS dissertation, Ocean University of China, Qingdao (in Chinese with English Abstract)

*Westermann P, Ahring BK, Mah RA (1989) Temperature compensation in Methanosarcina barkeri by modulation of hydrogen and acetate affinity. Appl Environ Microbiol 55:1262-1266

Williams RT, Crawford RL (1984) Methane production in Minnesota peatlands. Appl Environ Microbiol 47:1266-1271

WMO (World Meteorological Organization) (2017) The state of greenhouse gases in the atmosphere based on global observations through 2016. WMO Greenhouse Gas Bull No. 13. WMO, Geneva

* Xiao S, Liu D, Wang Y, Yang Z, Chen W (2013a) Temporal variation of methane flux from Xiangxi Bay of the Three Gorges Reservoir. Sci Rep 3:2500

K Xiao S, Wang Y, Liu D, Yang Z, Lei D, Zhang C (2013b) Diel and seasonal variation of methane and carbon dioxide fluxes at site Guojiaba, the Three Gorges Reservoir. J Environ Sci (China) 25:2065-2071

Xing Y, Xie P, Yang H, Ni L, Wang Y, Rong K (2005) Methane and carbon dioxide fluxes from a shallow hypereutrophic subtropical Lake in China. Atmos Environ 39:5532-5540

Xing Y, Xie P, Yang H, Wu A, Ni L (2006) The change of gaseous carbon fluxes following the switch of dominant producers from macrophytes to algae in a shallow subtropical lake of China. Atmos Environ 40:8034-8043

*Xiong Y, Wang F, Guo X, Liu F, Dong S (2017) Carbon dioxide and methane fluxes across the sediment-water interface in different grass carp Ctenopharyngodon idella polyculture models. Aquacult Environ Interact 9: 45-56

Yang P, Zhang Y, Lai DY, Tan L, Jin B, Tong C (2018) Fluxes of carbon dioxide and methane across the water-atmosphere interface of aquaculture shrimp ponds in two subtropical estuaries: the effect of temperature, substrate, salinity and nitrate. Sci Total Environ 635:1025-1035

* Yokoyama H (2013) Growth and food source of the sea cucumber Apostichopus japonicus cultured below fish cages-potential for integrated multi-trophic aquaculture. Aquaculture 372-375:28-38

Yu Z, Zhou Y, Yang H, Ma YE, Hu C (2014) Survival, growth, food availability and assimilation efficiency of the sea cucumber Apostichopus japonicus bottom-cultured under a fish farm in southern China. Aquaculture 426-427: 238-248 
Appendix. Estimates of fixed effects and covariance parameters

Table A1. Estimates of the fixed effects. T: sampling time; PM: polyculture system of swimming crab with kuruma shrimp; PMR: polyculture system of swimming crab with kuruma shrimp and short-necked clam; WV: wind velocity; AT: air temperature; $\mathrm{S}$ : salinity; $\mathrm{pH}_{\text {water }}$ : water $\mathrm{pH}_{\text {; }} \mathrm{DO}$ : dissolved oxygen; $\mathrm{RP}_{\text {water }}$ : redox potential in water; $\mathrm{TN}$ : total nitrogen; $\mathrm{TP}$ : total phosphorus; $\mathrm{pH}_{\text {sediment }}$ : $\mathrm{pH}$ in sediment; $\mathrm{RP}_{\text {sediment }}$ : redox potential in sediment;

$\mathrm{OM}_{\text {sediment }}$ organic matter content in sediment; (-) no data available

\begin{tabular}{|c|c|c|c|c|c|}
\hline Parameter & Estimate & $\mathrm{SE}$ & $d f$ & $t$ & $\mathrm{p}$ \\
\hline Intercept & -694.178 & 419.726 & 25.408 & -1.654 & 0.110 \\
\hline $\mathrm{T}$ & 0.035 & 6.977 & 23.515 & 0.005 & 0.996 \\
\hline PM & -31.112 & 42.350 & 33.508 & -0.735 & 0.468 \\
\hline PMR (reference) & 0 & 0 & - & - & - \\
\hline $\mathrm{PM} \times \mathrm{T}$ & 10.494 & 5.446 & 29.555 & 1.927 & 0.064 \\
\hline $\mathrm{PMR} \times \mathrm{T}$ (reference) & 0 & 0 & - & - & - \\
\hline WV & -10.436 & 6.458 & 32.882 & -1.616 & 0.116 \\
\hline $\mathrm{AT}$ & 13.535 & 3.306 & 28.896 & 4.094 & 0.000 \\
\hline $\mathrm{S}$ & -15.079 & 8.509 & 32.601 & -1.772 & 0.086 \\
\hline $\mathrm{pH}_{\text {water }}$ & 101.496 & 42.311 & 24.043 & 2.399 & 0.025 \\
\hline DO & 9.424 & 4.599 & 32.881 & 2.049 & 0.048 \\
\hline $\mathrm{RP}_{\text {water }}$ & 0.261 & 0.267 & 31.349 & 0.979 & 0.335 \\
\hline Chl a & -0.689 & 0.368 & 28.750 & -1.872 & 0.071 \\
\hline $\mathrm{NO}_{3}{ }^{-}-\mathrm{N}$ & 74.319 & 51.618 & 32.654 & 1.440 & 0.159 \\
\hline $\mathrm{NO}_{2}{ }^{-}-\mathrm{N}$ & -132.472 & 152.682 & 33.701 & -0.868 & 0.392 \\
\hline $\mathrm{NH}_{4}{ }^{+}-\mathrm{N}$ & -171.887 & 196.769 & 27.989 & -0.874 & 0.390 \\
\hline $\mathrm{PO}_{4}^{3-}-\mathrm{P}$ & 461.918 & 650.985 & 30.665 & 0.710 & 0.483 \\
\hline $\mathrm{TN}$ & -13.226 & 14.951 & 21.715 & -0.885 & 0.386 \\
\hline TP & -161.099 & 100.709 & 30.424 & -1.600 & 0.120 \\
\hline $\mathrm{pH}_{\text {sediment }}$ & 12.000 & 24.776 & 30.501 & 0.484 & 0.632 \\
\hline $\mathrm{RP}_{\text {sediment }}$ & 0.656 & 0.285 & 31.262 & 2.305 & 0.028 \\
\hline $\mathrm{OM}_{\text {sediment }}$ & -2.878 & 11.988 & 30.941 & -0.240 & 0.812 \\
\hline
\end{tabular}

Table A2. Estimates of covariance parameters. AR1: first-order autoregressive

\begin{tabular}{|llcccc|}
\hline Parameter & & Estimate & SE & Wald $Z$ & Sig. \\
\hline Repeated measures & AR1 diagonal & 488.439 & 125.223 & 3.901 & 0.000 \\
& AR1 rho & -0.101 & 0.260 & -0.389 & 0.697 \\
Intercept + system & AR1 diagonal & 7.131 & 25.726 & 0.277 & 0.782 \\
& AR1 rho & 0.414 & 2.398 & 0.173 & 0.863 \\
\hline
\end{tabular}

Editorial responsibility: Adam Hughes, Oban, UK
Submitted: April 23, 2018; Accepted: December 4, 2018 Proofs received from author(s): February 6, 2019 